\title{
Interventions to Improve Medication Adherence in Aged People with Chronic Disease - Systematic Review
}

\author{
Claudia Jorge de Sousa Oliveira ${ }^{1, *}$, Helena José $^{2}$, Alexandre Castro Caldas ${ }^{1}$ \\ ${ }^{1}$ Institute of Health Sciences, Catholic University of Portugal, Lisbon, Portugal \\ ${ }^{2}$ Multiperfil Health School, Angola
}

Copyright $(2017$ by authors, all rights reserved. Authors agree that this article remains permanently open access under the terms of the Creative Commons Attribution License 4.0 International License

\begin{abstract}
Currently, demographic trends, at a global level, are characterized by an increase in the older age group. Associated to advanced age, older people are more prone to chronic diseases, and they are confronted with the need to adhere to an often complex medication regimen. Non-adherence has a negative impact at individual and global level. The purpose of this systematic review was answering the question "What are the nursing interventions able to improve in medication adherence in aged people with chronic disease?". The search was conducted in PubMed (including MEDLINE), CINAHL, LILACS, SciELO and EMBASE, on January 2015, without time limit; the articles were selected according to the inclusion and exclusion criteria. It was used the PICOS method for the critical analysis. The electronic search identified 9 articles meeting the inclusion criteria. Interventions to improve medication adherence among the elderly should be complex and adapted to the factors of non-adherence. Strategies to improve medication adherence in older adults include educational and behavioral approach. Nurses need to lead the way in researching interventions that can affect medication adherence in older people, working with the current generation to develop plans that meet their needs and using interventions that make sense to them.
\end{abstract}

Keywords Aged, Medication Adherence, Intervention Studies, Chronic Disease

\section{Introduction}

Demographic trends, at a global level, have been characterized by an increase in the older age group. It is predicted that by 2025 there will be 1.2 billion people over 60 years old in the world [1]. It is a challenge ageing with autonomy, self-determination, and independence, thus maintaining their dignity and integrity [2].

Due to physiological ageing changes and lifestyles adopted throughout life, aged people are more prone to have chronic diseases, and frequently they are confronted with an often complex medication regimen [4]. The World Health Organization estimated that, by 2020, the number of Americans affected by at least one chronic condition, requiring medication therapy, will be 157 million [4-5].

Adherence to the medication regimen is related to timing, dosage, and frequency in the day-to-day routine and the medication persistence is related to the consistency in taking a prescribed medication for a determined length of time [6]. Thus, it is intended that the elderly are at a level of adherence and persistence, otherwise they will be considered as non-adherente to medication. Unfortunately, poor medication adherence is relatively common [4-5]. Several studies have consistently shown that $40 \%$ to $75 \%$ of patients do not take their medication as prescribed [6]. The ratio of adherence in developing countries is lower [1].

Not only is this lack of adherence prevalent but, it also has dramatic effects on individual and population health level $[1-2,7]$. The poor medication adherence leads to unnecessary disease progression, disease complications, reduced functional abilities, hosptalizations and institutionalization in nursing homes, a lower quality of life, health costs, and even death [1,8-9].

In the United States, non-adherence causes about 30\% to $50 \%$ of treatment failures, 125.000 annual deaths [5,10-11] and, it has been estimated to cost the health system between 100 billion to 289 billion dollars per year [5-12]. In Portugal, the costs associated with non-adherence to medication is not properly documented, however, according with a study the scenario is quite similar, it is estimated that 43.000 patients per year are admitted to hospitals in result of errors related to the intake of drugs [13].

Adherence behavior is a complex area with psychological, biomedical and anthropological explanations contesting for attention [14]. In literature we found evidence that educational and behavioral interventions can increase medication adherence and health gains. As for the costs associated to non-adherence and their impact on the quality of life, we found results without strong evidence. However, it is consensual the need of doing more research in this field. 
It is essential to understand the reason of non-adherence to achieve the change of behavior. Non-adherence to medication is a health phenomenon with a huge impact on the practice, especially in primary care, which affects a large number of the elderly [2,15]. Nowadays, we have an increase in the older age group with all their needs and, every day, nurses are face to face with them. So, it is imperative that nurses are acquainted with the best available evidence to fight this worldwide problem.

Agreeing with the available evidence about this issue it is possible to enhance medication adherence among older people, but a complex intervention is required. Therefore, it is an urgent worldwide challenge of the $21^{\text {st }}$ century innovating in intervention strategies for health care [1].

\section{Materials and Methods}

A systematic review of the literature was performed in order to identify, select, evaluate and synthesize research evidence in order to systematize the state of knowledge of nursing interventions to improve medication adherence in older people with chronic disease.

The guidelines of the Joanna Briggs Institute [16] were considered from the PICO (participants, interventions, comparison and outcomes) strategy for a research question, which was defined as: What are the nursing interventions able to improve in medication adherence in aged people with chronic disease? Each dimension of PICO question contributed to the definition of the inclusion and exclusion criteria (Figure 1).

Table 1. Inclusion and exclusion criteria for the systematic review

\begin{tabular}{|c|c|}
\hline Inclusion Criteria & Exclusion Criteria \\
\hline $\begin{array}{c}\text { Words "medication adherence" } \\
\text { present in title or abstract; }\end{array}$ & \\
Referring to older adults or/and & \\
aged people; & Referring to children or young \\
Nursing intervention to improve & adults; \\
medication adherence; & Being a dissertation or thesis; \\
Testing the effectiveness of & Interventions delivered by \\
interventions to improve & pharmacist and/or physicians; \\
medication adherence; & Interventions for short-term \\
Studies published in English, & medication prescription. \\
Portuguese, French or Spanish; & \\
Studies without time limit; & \\
Available in full text. & \\
\hline
\end{tabular}

The review is reported in conformity with the Joanna Briggs Institute criteria and PRISMA statement (Preferred Reporting Items for Systematic Reviews and Meta-Analysis).

The present study was made to explore the interventions used to enhance the medication prescribed to older people who live at home in a community, with at least a chronic disease. In this sense, this study, based on a rigorous scientific design, that allows to identify, evaluate and summarize the findings of several studies, and making accessible the best evidence-based practice. So, to evaluate the effectiveness of the intervention the principal outcome will be the ratio of medication taken according to the definition of medication adherence. However, other outcomes will be considered such as biochemical indicators.

Data collection was carried out from January 2015 in PubMed (including MEDLINE), CINAHL, LILACS, SciELO and EMBASE. Search strategies contained the follow descriptor DeCS/MeSH: "medication adherence" AND "interventions" AND "aged and over" AND "nurs*". No restrictions were used concerning publication date, because we did not find previous systematic review with the same objective.

There were 742 articles identified in our search, 24 articles which were duplicated were rejected. After reading the titles and abstracts of all articles, applying the inclusion and exclusion criteria, 677 were rejected. After the full reading 32 more articles were eliminated, having 9 articles been accepted for the present systematic review (Figure 1).

All articles were screened on title and abstract by two independent reviewers ( $\left.\mathrm{OC}^{*}, \mathrm{JH}^{* *}\right)$, and included if the title or abstract described interventions for enhancing medication adherence. After initial selection, remaining articles were screened full text by the same two researchers, and were included if the interventions of medications adherence were tested in concerning the effectiveness among older people with chronic disease. The researchers screened all articles included in the present systematic review.

The included studies predominantly used patients' records to assess the effectiveness of the intervention. This method incorporates a high risk of bias. The second problem faced was the fact that the included studies incorporated a variability of designs and methods. Therefore, an overall comparison between the studies was difficult. Third, the included studies used several synonyms and definitions of adherence, including compliance. Furthermore, because the literature presents a publication bias towards positive studies, the effect size of adherence improvement methods is likely to have been overestimated.

To provide a quality indicator, a pair of independent researchers $(\mathrm{OC}, \mathrm{JH})$ assessed the quality of all included studies. For this assessment we used the JBI Critical Appraisal Checklist for Systematic Reviews and Research Syntheses. The purpose of this appraisal is to assess the methodological quality of the studies included.

\section{Results and Discussion}

The electronic search identified 9 articles meeting the inclusion criteria. After a critical analysis of the selected articles, as well as the eligibility, credibility and relevance of the data, 2 articles were guided by a inductive paradigm, 6 by a deductive paradigm and 1 was based on mixed methods.

With regards to the country, the highest number of studies selected was provided by the United States of America (6). China, Portugal and Italy published 1 study each.

The selected articles are summarized concerning participants and study design on the following Table 2 .

\footnotetext{
* Oliveira CJS

** José H
} 


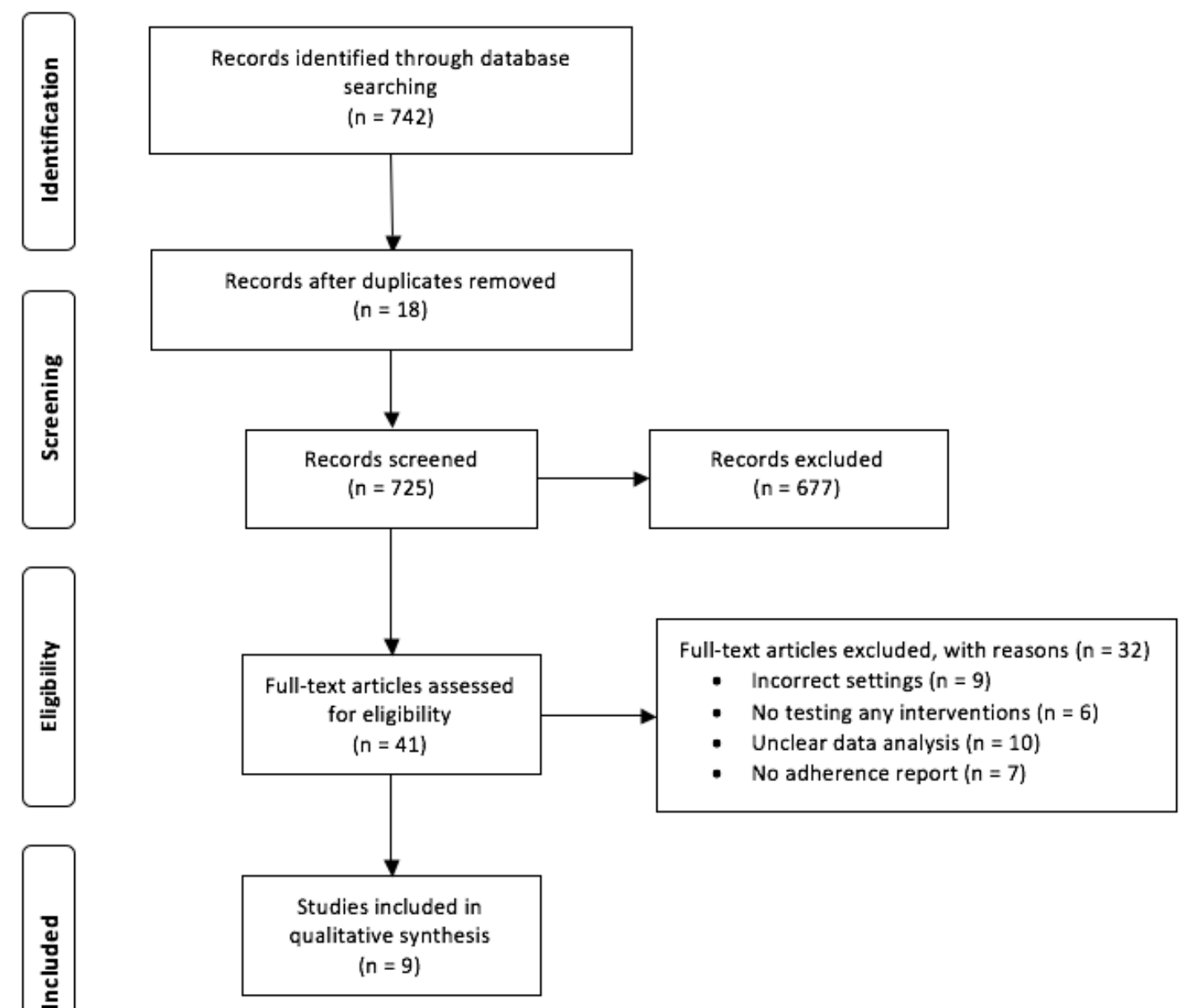

Figure 1. Identification, analysis and selection of the articles

Table 2. Selected articles - Author(s), Participants and Study Design

\begin{tabular}{|c|c|c|c|}
\hline Study & $\begin{array}{c}\text { Author(s), } \\
\text { Year and Country }\end{array}$ & Participants (P) & Study Design (S) \\
\hline 1 & Logue, 2002 [17] USA & Aged people with chronic disease treated with multiple medications. & Qualitative Study \\
\hline 2 & Lee et al, 2013 [8] China & $\begin{array}{l}\text { Older population ( } 65 \text { years or older), without family support, social life } \\
\text { and network, and not linked to the existing network support. A total of } 93 \\
\text { participants were recruited and } 86 \text { participants completed the study. }\end{array}$ & Prospective pilot study \\
\hline 3 & $\begin{array}{l}\text { Henriques, Costa and Cabrita, } \\
2012 \text { [2] Portugal } \\
\end{array}$ & People aged 65 years or more with chronic disease. & $\begin{array}{l}\text { Descriptive qualitative } \\
\text { study }\end{array}$ \\
\hline 4 & $\begin{array}{l}\text { Bogner, Morales, Vries and } \\
\text { Cappola, 2012 [18] USA }\end{array}$ & $\begin{array}{l}180 \text { patients prescribed pharmacotherapy for type } 2 \text { Diabetes and } \\
\text { depression in primary care. }\end{array}$ & $\begin{array}{l}\text { Randomized controlled } \\
\text { trial }\end{array}$ \\
\hline 5 & $\begin{array}{c}\text { Antonicelli, Mazzanti, } \\
\text { Abbatecola and Parati, } 2012 \\
\text { [19] Italy } \\
\end{array}$ & 57 aged patients with chronic disease (congestive heart failure). & $\begin{array}{l}\text { Randomized controlled } \\
\text { trial }\end{array}$ \\
\hline 6 & Solomon et al, 2012 [20] USA & Older adults with chronic condition (osteoporosis). & $\begin{array}{l}\text { Randomized Controlled } \\
\text { Trial } \\
\end{array}$ \\
\hline 7 & Kreps et al, 2010 [21] USA & $\begin{array}{l}\text { Seventeen male and thirteen female participants were recruited from the } \\
\text { Harris Interactive Chronic Illness Panel. }\end{array}$ & Mixed Method \\
\hline 8 & Friedman et al, 1996 [22] USA & Patients were 60 years or older with hypertension. & $\begin{array}{l}\text { Randomized controlled } \\
\text { trial }\end{array}$ \\
\hline 9 & $\begin{array}{l}\text { Heisler, Vijan, Makki and } \\
\text { Piette, } 2010 \text { [23] USA }\end{array}$ & $\begin{array}{l}\text { Veterans with diabetes and poor glycemic control (126 participants in the } \\
\text { intervention group, and } 119 \text { participants in the control group). }\end{array}$ & $\begin{array}{l}\text { Randomized controlled } \\
\text { trial }\end{array}$ \\
\hline
\end{tabular}


Table 3. Critical analysis of the studies (Interventions, Comparisons and Outcomes)

\begin{tabular}{|c|c|c|c|}
\hline Study & Interventions (I) & Comparisons (C) & Outcomes (O) \\
\hline 1 & $\begin{array}{l}\text { An education intervention to successful } \\
\text { elder self-medication management: } \\
\text { knowledge empowerment, self-efficacy } \\
\text { enhancement and positive reinforcement. }\end{array}$ & Not applied (N/A) & $\begin{array}{l}\text { Advanced practice nursing on improving } \\
\text { medication adherence (educational and clinical } \\
\text { expertise) in the elderly is related with the } \\
\text { enhancement of therapeutic elder self-care, the } \\
\text { promotion of elder independence and the } \\
\text { reduction of healthcare costs. }\end{array}$ \\
\hline 2 & $\begin{array}{l}\text { Home visits. The nurses focuses on dietary } \\
\text { education, home injury prevention and } \\
\text { relaxation therapy, whereas the pharmacist } \\
\text { focuses on drug-related issues. }\end{array}$ & N/A & $\begin{array}{l}\text { After the intervention, the mean Morisky score } \\
\text { decreased by } 0.61 \text {, signifying improvement of } \\
\text { medication adherence }(P<0.001) \text {. }\end{array}$ \\
\hline 3 & $\begin{array}{c}\text { Explore the strategies used for medication } \\
\text { management by the elderly who live at } \\
\text { home in community. }\end{array}$ & N/A & $\begin{array}{l}\text { The relationship between health professionals } \\
\text { and older people is essential in medication } \\
\text { management and the elderly group reported that } \\
\text { the information given by the nurse during } \\
\text { consultation is very important. Nursing } \\
\text { interventions (education, teaching and training) } \\
\text { are the key for patients to increase their } \\
\text { medication. }\end{array}$ \\
\hline 4 & $\begin{array}{l}\text { Integrated care intervention. The key } \\
\text { components of the intervention were the } \\
\text { provision of an individualized programme } \\
\text { to improve adherence. The interventions } \\
\text { consisted in-personal sessions, telephone } \\
\text { contacts, and collaborating care with the } \\
\text { physician. The intervention was presented } \\
\text { as a supplement of the existing primary care } \\
\text { treatment. }\end{array}$ & $\begin{array}{c}\text { The usual care consisted in-person } \\
\text { session at baseline, } 6 \text { weeks, and } 12 \\
\text { weeks }\end{array}$ & $\begin{array}{l}\text { Adherence was assessed using the medication } \\
\text { event monitoring system. They used glycated } \\
\text { haemoglobin assays to measure glycemic } \\
\text { control. Patients who received the interventions } \\
\text { were more prone to achieve glycated } \\
\text { haemoglobin levels of less than } 7 \% \\
\text { (intervention } 60.9 \% \text { vs usual care } 35,7 \% \text {. } P \\
<0.001 \text { ). The intervention group and usual care } \\
\text { group did not differ statistically on base-line } \\
\text { measures. At } 6 \text { and } 12 \text { weeks, a significant } \\
\text { improvement in adherence to oral medication } \\
\text { was seen in the intervention group in } \\
\text { comparison with the usual care group. }\end{array}$ \\
\hline 5 & $\begin{array}{l}\text { The experimental group received a home } \\
\text { telemonitoring intervention. Patients were } \\
\text { contacted monthly by telephone at least } \\
\text { once a week to obtain information. }\end{array}$ & $\begin{array}{l}\text { Control group - received standard care } \\
\text { based on routinely scheduled clinic } \\
\text { visits from a specialized team ( } 12 \\
\text { months follow-up). Patients (or one of } \\
\text { their relatives) were contacted monthly } \\
\text { by telephone to obtain data. }\end{array}$ & $\begin{array}{l}\text { The experimental group had a significant } \\
\text { increase in medication adherence. Adherence to } \\
\text { prescribed medication in the experimental } \\
\text { group was } 89,7 \% \text { and in the control group it was } \\
35,7 \%(P<0.03) \text {. This study showed that a } \\
\text { home-care model including telemonitoring of } \\
\text { relevant clinical parameters may provide useful } \\
\text { support in the improvement of medication } \\
\text { adherence. }\end{array}$ \\
\hline 6 & $\begin{array}{l}\text { The interventions consisted of one-on-one } \\
\text { telephone based counselling using a } \\
\text { motivational interviewing approach, and } \\
\text { the mailed education. The counselling } \\
\text { sessions included a scripted dialogue, } \\
\text { open-ended questions about medication } \\
\text { adherence and its barriers }\end{array}$ & $\begin{array}{l}\text { Mailed educational materials } \\
\text { comprised seven topics: basic } \\
\text { information about osteoporosis and } \\
\text { fractures; the appropriate use of } \\
\text { osteoporosis medications; how to talk } \\
\text { with your doctor about medications; } \\
\text { fall preventions through home safety; } \\
\text { sufficient calcium and vitamin D } \\
\text { through diet and supplements; } \\
\text { exercises to improve balance; and bone } \\
\text { mineral density testing. }\end{array}$ & $\begin{array}{l}\text { The study did not demonstrate a statistically } \\
\text { significant improvement in adherence to a } \\
\text { medication regimen associated with } \\
\text { telephone-based motivational interviewing } \\
\text { counselling interventions. The intervention may } \\
\text { be more effective in specific populations, } \\
\text { including patients aged } 75 \text { years or older } \\
\text { compared with those aged } 65 \text { to } 74 \text { years. }\end{array}$ \\
\hline 7 & $\begin{array}{l}\text { Motivational message to improve } \\
\text { medication adherence according with } \\
\text { Weick's model. The model suggests three } \\
\text { phases: enactment, selection and retention. }\end{array}$ & N/A & $\begin{array}{l}\text { Exposure to motivational messages increased } \\
\text { patient' intention to adhere to medication } \\
\text { recommendations }\end{array}$ \\
\hline 8 & $\begin{array}{l}\text { The intervention group received regular } \\
\text { medical care plus telephone-linked } \\
\text { computer system. This is an interactive } \\
\text { computer-based telecommunication system } \\
\text { that speaks with patients in their homes, } \\
\text { using computer-controlled speech. During } \\
\text { the conversation, participants would answer } \\
\text { a standard series of questions and the } \\
\text { telephone-linked computer system would }\end{array}$ & $\begin{array}{l}\text { Control group received regular medical } \\
\text { care. }\end{array}$ & $\begin{array}{l}\text { The antihypertensive medication adherence } \\
\text { improved } 17.7 \% \text { for telephone system users and } \\
11.7 \% \text { for patients in the control group. } \\
(P=0.03) \text {. The majority of telephone system } \\
\text { users were satisfied with the system. This } \\
\text { system was cost-effective, especially for } \\
\text { non-adherent patients. }\end{array}$ \\
\hline
\end{tabular}




\begin{tabular}{|c|c|c|c|}
\hline & $\begin{array}{c}\text { provide education and motivational } \\
\text { counselling to improve medications } \\
\text { adherence. }\end{array}$ & & \\
\hline 9 & $\begin{array}{l}\text { The intervention group received a } \\
\text { reciprocal peer support. Patients included in } \\
\text { this group attended a 3-hour group session } \\
\text { facilitated by a care manager and a research } \\
\text { associate. Patients were encouraged to call } \\
\text { each other at least once a week using an } \\
\text { interactive, voice-response-facilitated } \\
\text { telephone platform. At the end of the initial } \\
\text { session, patients were given a DVD that } \\
\text { demonstrated peer communication skills } \\
\text { and a diabetes self-management workbook } \\
\text { that they could use to help guide their peer } \\
\text { telephone calls. }\end{array}$ & $\begin{array}{l}\text { In the control group patients received } \\
\text { nurse care management. Patients in this } \\
\text { group attended a } 1.5 \text {-hour session, led } \\
\text { by a care manager, to review their } \\
\text { laboratory and blood pressure results, } \\
\text { ask questions, and receive information } \\
\text { on veterans affairs care management } \\
\text { services. They were provided with their } \\
\text { assigned care manager's contact } \\
\text { information and encouraged to } \\
\text { schedule follow-up telephone calls and } \\
\text { face-to-face visits with their care } \\
\text { manager. Each patient diabetes was } \\
\text { provided self-management educational } \\
\text { materials. }\end{array}$ & $\begin{array}{l}\text { Many chronically ill patients need more support } \\
\text { for self-care than most health care systems can } \\
\text { provide, models that increase the quality and } \\
\text { intensity of assistance through peer support, } \\
\text { deserve further exploration. Reciprocal peer } \\
\text { models can be an effective and efficient } \\
\text { approach in helping older people in this stage of } \\
\text { life. Periodic nurse-facilitated, patient-driven } \\
\text { group sessions supplemented with one-on-one } \\
\text { peer-support telephone calls between } \\
\text { age-matched partners improved medication } \\
\text { adherence and glycemic control among diabetic } \\
\text { men. }\end{array}$ \\
\hline
\end{tabular}

All the gathered studies evidenced relevant information to the answer to the initial question of this research. The results obtained are summarized on the Table 3 .

One of the biggest challenges of nursing is to prepare and help people to respond positively to the changes occurring in their lives. The experience of a transition health/disease is a challenge to which people are rarely prepared and which perceive not to possess the necessary skills and knowledge to maintain their self-control. Upon diagnosis of a chronic disease older people need to adhere, not only, but also to a medication regimen, often complex. The primary goal of this study was to identify effective nursing interventions for older people with chronic disease who live at home in the community, able to enhance medication adherence. According to the results of this systematic review, it is not just a matter of adherence, but also an issue of management of the medication prescribed $[2,8,21,23]$. In this systematic review we found evidence of effective interventions that should be replicated and re-tested in different target population, with the aim to promote well-being in older people, helping them to live with dignity and autonomy.

The interventions to improve medication adherence among older people with chronic disease should be complex and adapted to the factors of non-adherence [2, 17-18, 21].

Strategies to improve medication adherence in older adults include appropriate formats for medication information, feedback about medication-taking patterns, inpatient self-medication programs, and external organizers [17-18, 21, 23].

Educational and clinical expertise in the geriatric population is an asset in this area, so nurses should develop and implement patient-centered educational efforts [2, 8, 23]. Information sharing and educational initiatives were measured and can improve adherence but alternative interventions should also be explored [8, 21, 23].

Individualized teaching, learning strategy and a medication information leaflet with each patient's discharge plan should be considered [8, 17]. Nursing interventions (education, teaching and training) help the patient to understand the issues related to the treatment and the medication.
According with two studies, home-care model including telemonitoring, increases medication adherence and reduces hospitalization and mortality [19, 22], but another research did not demonstrate a statistically significant improvement in adherence to medication regime associated with a telephonic intervention [20]. Subgroup analysis suggests that the intervention may be more effective in specific populations [20].

However, the systematic review showed that no single method is reliable and accurate. A single intervention may not be enough to produce a sustained change in adherence behavior and a combination approach together with a constant reinforcement, may be required. The management of medicines in the elderly is a complex process, which 'covers the process and support systems that are available to help the ones who self-administer medication to get the best benefit of health prescription drugs' [2].

Recommendations ranging from measurement of adherence, communication from healthcare provider to patient, education about treatment, dose administration, scheduling of clinic visits can enhance the medication prescribed and help patients to develop their own skills to manage the medication. A multifaceted intervention implies that more barriers can be targeted, but it does not mean that these barriers are always targeted more effectively [17, 23].

The effect of the intervention also depends on the quality of the interventions [17, 21,23]. Practical interventions such as simplifying dosage regimens and ensuring that packaging is patient-friendly should be included in any approach to improving adherence $\left[17-18^{]}\right.$. The relationship between health professionals and patients is recognized as indispensable and essential in disease management and medication [2].

There is consensus in the scientific community that the nursing interventions can improve medication adherence, however they should be adapted to the self-care level of each person.

\section{Conclusions}

The issue of medication adherence in older people with 
chronic disease is a real problem with direct effect in the individual and social level. The patients have a continuing need for medical attention, which results in impacts in the healthcare costs and quality of life.

Our study provides a sustainable solution; nursing interventions should be implemented in primary care or other settings for patients managing multiple medical conditions and varying degrees of complexity in pharmacotherapeutic regimens. It is vital to explore different strategies to improve specific needs in older people. Nurses are in a good position to be involved in programmes able to promote the adherence to medication and, consequently, improve the general well-being of older people who live in the community in their homes.

Nurses need to lead the way in researching interventions that can affect medication adherence in older adults, working with the current generation of older adults to develop plans that meet their needs and using interventions that make sense to them. Nurses can contribute to finding solutions to medication adherence through policy, systems, practice, and research, with the first step being effective communication with older adults and their caregivers.

No single strategy or programmatic focus led to significant improvements in patients' adherence generally, but comprehensive interventions combining cognitive, behavioral and affective components are more effective than single interventions. Promoting best practices, behaviors, and technologies may significantly improve medication adherence.

This study thus becomes crucial to our future goal of testing a complex nursing intervention tailored to the needs of people according to their level of self-care, to promote medication adherence. All studies analyzed affirmed the need for more research in this area to try to combat this scourge that unfortunately leads to considerable damage.

\section{Acknowledgements}

We are very grateful to experts for their appropriate and constructive suggestions to improve this template.

\section{REFERENCES}

[1] World Health Organization. Adherence to long-term therapies: evidence for action. Geneva (SWZ): World Health Organization; 2003 [accessed 201510 October]. Online available: http://apps.who.int/iris/bitstream/10665/42682/1/9 241545992.pdf

[2] Henriques MA, Costa MA, Cabrita J. Adherence and medication management by the elderly. Journal of Clinical Nursing. 2012; 21:3096-3105. Doi: 10.1111/j.1365-2702.20 12.04144.x

[3] Kocurek B. Promoting medication adherence in older adults... and the rest of us. Diabetes Spectrum. 2009; 22(2):
80-84.

[4] Osterberg L, Blaschke T. Adherence to medication. Drug Therapy. 2005 August [accessed $2015 \quad 8$ January]; 353(4):487-497. Online available: http://www.ub.edu/farmac iaclinica/projectes/webquest/WQ2/docs/osterberg.pdf

[5] Ho PM, Bryson CL, Rumsfeld JS. Medication adherence: Its importance in cardiovascular outcomes. Circulation (American Heart Association). 2009; 119(23): 3028-3035. Doi: 10.1161/CIRCULATIONAHA.108.768986. Online available: http://circ.ahajournals.org/contente/119/23/3028

[6] Nieuwlaat R, Wilczynski N, Navarro T, Hobson N, Jeffery R, Keepanasseril A, et al. Interventions for enhancing medication adherence. Cochrane Database of Systematic Reviews. 2014; 11. Art. No.: CD000011. Doi: 10.1002/1465 1858.CD000011.pub4.

[7] Viswanathan M, Golin CE, Jones CD, Ashok M, Blalock S, Wines RCM, et al. Medication Adherence Interventions: Comparative Effectiveness. Closing the Quality Gap: Revisiting the State of the Science. Evidence Report No. 208. (Prepared by RTI International-University of North Carolina Evidence-based Practice Center Research Triangle Park, NC. AHRQ Publication No. 12-E010-EF. Rockville, MD: Agency for Healthcare Research and Quality. 2012 September [accessed 20158 January]. Online available: www.effective healthcare.ahrq.gov/reports/final.cfm

[8] Lee VWY, Pang KKW, Hui KC, Kwok JCK, Leung SL, Yu DSF et al. Medication adherence: Is it a hidden drug-related problem in hidden elderly? Geriatr Gerontol Int. 2013; 13: 978-985. Doi: 10.1111/ggi.12042

[9] Doggrell S. Adherence to medicines in the older-aged with chronic condition: does an intervention concerning adherence by an allied health professional help' Drugs Aging. 2010 [accessed 201512 October]; 27(3):239-254. Online available: http://eprints.qut.edu.au/38307/1/c38307.pdf

[10] Edmondson D, Horowitz CR, Goldfinger JZ, Fei K, Kronish IM. Concerns about medications mediate the association of post-traumatic stress disorder with adherence to medication in stroke survivors. Br J Health Psychol. 2013 November [accessed $2015 \quad 8$ October]; 18(4):799-813 doi: 10.1111/bjhp.12022. Online available: http://www.ncbi.nlm. nih.gov/pme/articles/PMC3760991/pdf/nihms470819.pdf

[11] Haugh, KH. Medication adherence in older adults. The pillbox half full. Nurs Clin N Am. 2014; 49: 183-199. Doi: 10.1016/j.cnur.2014.02.006

[12] Levine DA, Morgenstern LB, Langa KM, Piette JD, Rogers MA, Karve SJ. Recent trends in cost-related medication nonadherence among US stroke survivors. Annals of Neurology. 2013 [accessed 201510 October]; 73(2):180-188. doi: 10.1002/ana.23823. Online available: http://www.ncbi.n lm.nih.gov/pmc/articles/PMC3677727/pdf/nihms468624.pdf

[13] Guerreiro MP, Cantrill JA, Pisco L, Martins AP. Considerations on preventable drug-related morbidity in Primary Care. Part 1-Impact of preventable drug-related morbidity. Rev Port Clin Geral. 2005 [accessed 20157 October]; 25:269-79. Online available: https://www.research gate.net/publication/237717489_Considerations_on_prevent able_drug-related_morbidity_in_Primary_Care_Part_I_-_Im pact_of_preventable_drug-related_morbidity

[14] Russell CL, Ruppar TM, Matteson M. Improving Medication Adherence: Moving from Intention and Motivation to a 
personal systems approach. Nurs Clin N Am. 2011; 46: 271-281. Doi: 10.1016/j.cnur.2011.05.004

[15] Mahtani KR, Heneghan CJ, Glasziou PP, Perera R. Reminder packaging for improving medication adherence to self-administered long-term medications. Cochrane Database of Systematic Reviews. 2001; Issue 9. Art. No.: CD005025. Doi: 10.1002/14651858.CD005025.pub3.

[16] Joanna Brigs Institute. Critical Appraisal Tools for Use in JBI Systematic Reviews. Checklist for Systematic Review and Research Syntheses. 2016 [accessed 20168 September]. Online available: http://joannabriggs.org/research/critical-ap praisal-tools.html

[17] Logue R. The Impact of Advanced Practice Nursing of Improving Medication Adherence in the Elderly: An Educational Intervention. The American Journal for Nurse Practionners. 2002 May; 9-15.

[18] Bogner, HR, Morales KH, Vries HF, Cappola AR. Integrated Management of Type 2 Diabetes Mellitus and Depression Treatment to Improve Medication Adherence: A Randomized Controlled Trial. Annals of Family Medicine. 2012 [accessed 201515 January]; 10:15-22. Doi:10,1370/afm.1344 Online available: www.annfammed.org

[19] Antonicelli R, Maxxanti I, Abbatecola AM, Parati G. Impact of Home Patient Telemonitoring on Use of $\beta$-Blockers in Congestive Heart Failure. Drugs Aging. 2010 [accessed 2015
20 January]; 27(10):801-805. Doi: 10 , 2165/11538210-000000000-00000. Online available: http://www.researchgate.net/publication/47154761

[20] Solomon DH, Iversen MD, Avorn J, Gleeson T, Brookhart MA, Patrick AR, et al. Osteoporosis Telephonic Intervention to Improve Medication Regimen Adherence. A Large, Pragmatic, Randomized Controlled Trial. Arch Intern Med. 2012 [accessed 201514 January]; 172(6):477-483. Doi:10.1001/archinternmed.2011.1977 Online available: http://www.archinte.jamanetwork.com

[21] Kreps GL, Villagran MM, Zhao X, McHorney CA, Ledford C, Weathers $M$, et al. Development and validation of motivational messages to improve prescription medication adherence for patients with chronic health problems. Patient Education and Counseling. 2011; 1-7. Doi: 10,1016/j.pec201 1.04 .029

[22] Friedman RH, Kazis LE, Jette A, Smith MB, Stollerman J, Torgerson J, et al. A Telecommunications System for Monitoring and Counseling Patients with Hypertension. Impact on Medication Adherence and Blood Pressure Control. American Journal of Hypertension. 1996 April; 9(4): 285-292.

[23] Heisler M, Vijan S, Makki F, Piette JD. Diabetes Control with Reciprocal Peer Support versus Nurse Care Management: A Randomized Trial. Annals of Internal Medicine. 2010;153:507-515 